\title{
A COMPARATIVE STUDY ON THE RELATIONSHIP BETWEEN RESIDENTIAL DENSITY AND VEHICULAR ENERGY USE IN FLORIDA
}

\author{
$\underline{\text { Yongjin Joo }}^{1}$, Young Il $\mathrm{Kim}^{2}$, and Tae-Ho $\mathrm{Kim}^{3 *}$ \\ ${ }^{1}$ Institute of Urban Sciences, University of Seoul, Seoul, Korea \\ ${ }^{2}$ Graduate School of Urban Studies, Hanyang University, Seoul, Korea \\ ${ }^{3}$ Institute of Urban Sciences, University of Seoul, Seoul, Korea \\ *Corresponding author(traffix@uos.ac.kr)
}

\begin{abstract}
High population, vehicles, and employment and high energy use could generate congestion that has been considered as a result from diseconomies of agglomeration. However, congestion and energy use problem could be mitigated in a compact city due to shorter commuting distance, efficient vehicular operation, etc. US government and local state governments have been trying to redirect its energy use to address congestion and vehicular energy use. Household vehicle use, and fuel consumption, and VMT have primarily have been considered as main factors of vehicular emission. This paper analyzes NHTS 2001 combined with EIA augmentation data and Census data and to identify relationship between energy use by car and greenhouse gas emission, in particular, related to residential density. Major factors and variables are considered: VMT, vehicular energy use, urban density factor, household's socioeconomic factor, household's demographic factor. Two MSAs in Florida such as Miami, and Orlando are compared based upon the factors. This paper uses econometric methodology such as SEM (Structural Equation Model) to see complicated and causal relationship among variables. The results show that Miami is more energy efficient than Orlando because of less VMT and energy use per household unit. Furthermore, more vehicles, more drivers, more incomes, and more workers means high VMT and high energy use, which implies that they are more sprawl. To deal with this problem, impact fee might be one of the solutions.
\end{abstract}

Keywords: Urban Density, VMT, Energy Use, \& Compact Development

\section{INTRODUCTION}

Due to unstopped land development in suburban area and centralized employment, contemporary cities generate high population, many vehicles, and high energy use. As one asserts, this concentrated human festival for the 21 st century have brought urban problem: congestion. This might result from diseconomies of agglomeration, which is side effect of benefits of agglomeration. However, congestion and energy use problem could be mitigated in a compact city due to shorter commuting distance, and fewer vehicles traveled miles [13].

Increasing population and employment density in MSAs could reduce vehicle travel, energy use, and $\mathrm{CO} 2$ emissions. TRB (2009)'s literature review proposes that increasing residential density by twice throughout MSA might decrease household VMT by approximately 5 through maximum 25 percent as long as there is employment concentrations, public transit improvements, mixed uses. This is because distance to travel decreases and transit mode is more efficient than one in sprawled local area if a city is more compact [13]. Therefore, trip can be reduced by walking, biking, or using public transit so people commute more efficiently by using alternative transit mode. Indeed, empirical study presents that people tend to be more likely to commute by car in lowest density of work location but the closer work environment is, the less people use their car [8]. Also, Brownstone and Golob's results indicate that 1000 dwelling units per square mile decreases household's VMT by 1200 miles per year [1]. These researches imply that the more compact cities are, the less energy use and greenhouse gas (GHG) diverge. This might be explained by common assumption that an increasing 
population and land use development affect increasing energy use.

In the mean time, there is statistically significant study showing that transportation accounts for $40-60 \%$ of lifecycle GHG emissions in residential development and public transit accounts for $2-5 \%$ of total transportation energy use [8]. Therefore, it seems that understanding the relationship between energy use and residential density is appeared to be important in this era.

However, there have been studies that density negatively affects energy use [5]. Another study shows that there is no direct association between land use density and transportation energy consumption [10]. This indicates that there are still ongoing arguments that higher residential density causes cost and energy use and it is necessary to study for the relationship between vehicular energy use and residential density.

According to Monthly Energy Review released in March 2009 by U.S. Department of Energy, the growth of energy use in transportation and other end-use sector has been tracked for about 35 years from 1973 to 2008 [11]. This represents that for 35 years residential energy use has been top ranking out of four energy usage. In addition, demographic statistics from 1969 to 2001 show that even if persons per household decreases, vehicles per household, workers per household, vehicles per worker, and vehicles per licensed driver has been dramatically increased. This implies that the vehicle density per every household has been increased.

Therefore, this paper aims to show and analyze relationship between energy use in transportation and vehicle miles traveled, in particular, associated with residential density. In other words, the objective of this research is to provide evidence about the effects of residential density on vehicular energy use pattern and VMT. To that end, two questions will be addressed: What is the effect of residential Density on VMT? What is the effect of residential Density on Vehicular Energy Use?

The obtained data shows different mean, and standard deviation. Including dependent variables such as energy use and VMT, this dataset consist of several data groups: socioeconomic data, demographic data, and Urban Density data based upon which SEM is constructed and developed. To answer these questions in a comprehensive way, different economic methods such as CART analysis, t-test, correlation, collinearity analysis, factor score analysis and SEM (Structure Equation Modeling) will be combined and used. Specifically, socioeconomic data, urban density data, demographic data are drawn from factor score analysis combined with correlation and collinearity analysis. Only one study used SEM with bootstrapping method to avoid biased error. This paper only uses ML (maximumlikelihood) to find whether the hypothesis is consistent with the analysis results or not.

Last but not least, the research process flow is initially established in figure 1. This paper utilizes correlation, factor score analysis, and collinearity analysis to set up and obtain fundamental data with SAS 9.1 and SPSS 15.0. To develop SEM, it uses Lisrel (ver 8.51).

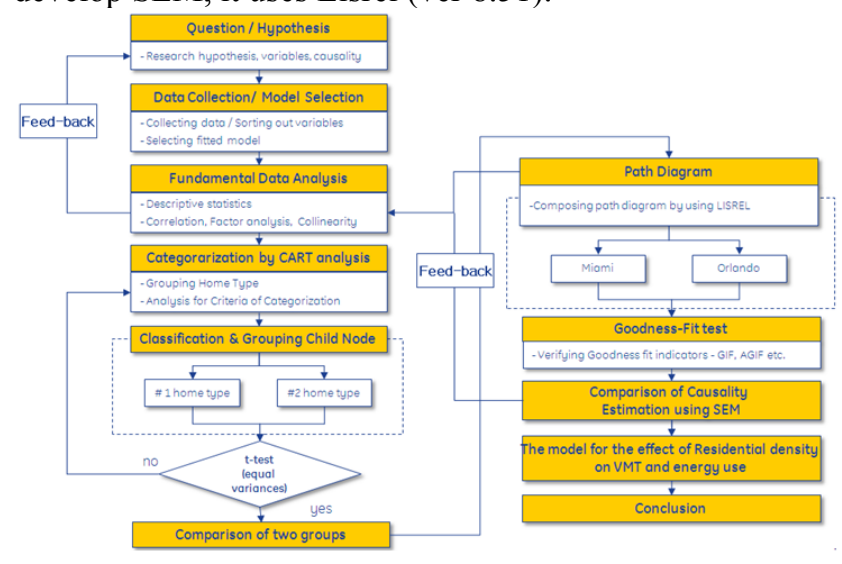

Fig. 1 Research Process Flow Chart

\section{Data}

To collect data, several questions about premises and hypothesis of obtained data should be addressed.

What are main determinants of VMT and energy use?

How do we obtain disaggregate dataset?

How much coefficient should be large enough?

How do we solve self-selection problem?

This paper uses 2001 NHTS conducted by USDOT which includes household based data, and random sample from USA. In 2004 EIA released augmented data of NHTS in 2004. This data contain explicated energy use data and VMT so two dataset combined and mingled to analyze.

First, it uses the 2001 NHTS data in order to get vehicle 
usage and fuel use data at a household level. The NHTS is the nation's tract storage of daily and long-distance travel. It includes demographic data such as the number of people, age, household, etc. The 2008 NHTS will be released to the public by next January. It'll be good to use the up-to-date dataset but 2001 NHTS data is the best dataset to be analyzed at this point. The three major factors can be pooled from this dataset: socioeconomic factor (household income, number of licensed drivers, the number of the employed, and the number of vehicles owned etc.), demographic factor (number of family member, number of adults etc) and energy use by transportation factor (annual fuel consumption, annual average vehicle mileage traveled etc.).

Second, this article uses Census tract dataset which allows comparing and clustering the datasets based upon the region, which indicates that, Miami, Orlando will be compared based on established factors. This part compares overall presences of residential characteristics in both two MSAs to make an assumption about residential behavior and transportation energy use. one major factor can be drawn in the dataset: urban density factor (housing units, the number of population, the number of household etc).

In order to stimulate land use factor, density, clustering, and mix factors can be used. As Todd Litman states that land use patterns can be evaluated based on several attributes including those three variables [12].

However, it takes long time to disaggregate the data on a spatial basis with addresses. Even though several studies show that economic characteristics such as income, gasoline price is not primarily important [6,7], those factors should be considered in that they generally generate urban sprawl [4].

By using the structural equation model (SEM), this paper examines the impact of residential density on energy use. Normal distribution test, correlation analysis, and collinearity analysis are conducted before using SEM. SEM requires endogenous variables and exogenous variables to calculate estimates of the model. Three major endogenous variables are mainly considered in this paper: density variables, VMT, and Energy Use. To use SEM, research hypothesis primarily should be established so as to compare itself with analysis results. The three research hypotheses are setup as seen in the table 1. As literature review stated above, the hypothesis is that compact development decreases VMT and energy use. As density grows in central city, population increases, the number of employers increase and thus total income is higher than suburban area. Therefore, the six hypotheses describe the relationship among the factor variables.

Table 1. Research Hypothesis

\begin{tabular}{l|l}
\hline No & \multicolumn{1}{|c}{ Description of research hypothesis } \\
\hline 1 & Socioeconomic factor positively related to VMT $(+)$ \\
\hline 2 & Socioeconomic factor positively related to Energy Use $(+)$ \\
\hline 3 & Demographic factor positively related to VMT $(+)$ \\
\hline 4 & Demographic factor positively related to Energy Use $(+)$ \\
\hline 5 & Urban Density positively related to VMT $(+)$ \\
\hline 6 & Urban Density factor positively related to Energy Use $(+)$ \\
\hline
\end{tabular}

\section{Analysis}

Descriptive Statistics (Table 2, p4) shows that higher density MSA represents less VMT and Energy Use. Maximum energy use in Miami presents 4263.84 gallon along with 87608.7 miles over 6,000 units per square miles whereas Orlando illustrates 4920.83 gallon, and 97462 miles in an area of 4,000 units per square miles.

Even though CHAID analysis is useful for multiple grouping, it provides F-test results for testing null hypothesis "there is no association between two groups." The results provide evidence that single house and row house (low density household) differ from apartment and condominium group (high density group) in based on regressed total energy use. Average of low density household's energy use is approximately 1109.04 gallons whereas; the average energy use of high density group shows just 687.45 gallons. This implies that low density household spread throughout suburban area rather than central city area. Further group analysis will not be conducted because only Miami is segmented into two density groups. Fig 2 below shows the result of CHAID analysis 
Table 2 Descriptive Statistics

\begin{tabular}{|c|c|c|c|c|c|c|c|c|c|c|c|c|c|}
\hline & & & \multirow{2}{*}{ Description } & \multicolumn{5}{|c|}{ Miami } & \multicolumn{5}{|c|}{ Olando } \\
\hline & & & & $\mathrm{N}$ & Min & $\operatorname{Max}$ & Mean & Std. & $\mathrm{N}$ & Min & Max & Mean & Std. \\
\hline \multicolumn{3}{|c|}{ Energy Use } & total gallon used & 171 & 0.33 & 4263.84 & 968.51 & 808.02 & 96 & 8.59 & 4920.83 & 1076.00 & 950.27 \\
\hline \multicolumn{3}{|c|}{ VMT } & total miles traveled & 171 & 5.32 & 87608.7 & 20074.04 & 17092.42 & 96 & 105 & 97462.37 & 21956.21 & 18364.59 \\
\hline \multirow{3}{*}{\multicolumn{2}{|c|}{ Urban Density }} & Residential Density & Housing units per sq mile-Tract & 171 & 25 & 6000 & 2576.75 & 1592.026 & 96 & 25 & 4000 & 1399.22 & 991.92 \\
\hline & & Employment Density & Workers per square mile living in Tract & 171 & -9 & 5000 & 2656.51 & 1365.3 & 96 & 25 & 5000 & 1469.01 & 1133.86 \\
\hline & & Population Density & Population in tract & 171 & 50 & 30000 & 7130.99 & 4885.88 & 96 & 50 & 7000 & 3231.77 & 2376.21 \\
\hline $\mathrm{H}$ & \multirow{4}{*}{ Socioeconomic } & \# drivers & Number of Drivers & 171 & 1 & 5 & 1.87 & 0.79 & 96 & 1 & 4 & 1.75 & 0.70 \\
\hline $\mathrm{O}$ & & \# workers & Number of Workers & 171 & 0 & 4 & 1.39 & 0.92 & 96 & 0 & 4 & 1.19 & 0.81 \\
\hline $\mathrm{U}$ & & Income & Annual Income level (1-9) & 171 & -9 & 9 & 5.23 & 5.29 & 96 & -9 & 9 & 6.07 & 3.39 \\
\hline $\mathrm{S}$ & & \# vehicles & Number of Vehicles owned & 171 & 1 & 7 & 1.92 & 1.03 & 96 & 1 & 6 & 1.83 & 0.89 \\
\hline E & \multirow{3}{*}{ Demographic } & \# Adults & Number of adults & 171 & 1 & 6 & 1.94 & 0.81 & 96 & 1 & 4 & 1.80 & 0.64 \\
\hline H & & Household Size & Number of household member & 171 & 1 & 8 & 2.57 & 1.38 & 96 & 1 & 6 & 2.33 & 1.25 \\
\hline $\begin{array}{l}\mathrm{L} \\
\mathrm{D}\end{array}$ & & Age & The first respondent's age & 171 & 20 & 88 & 49.64 & 16.67 & 96 & 19 & 88 & 48.67 & 16.02 \\
\hline
\end{tabular}

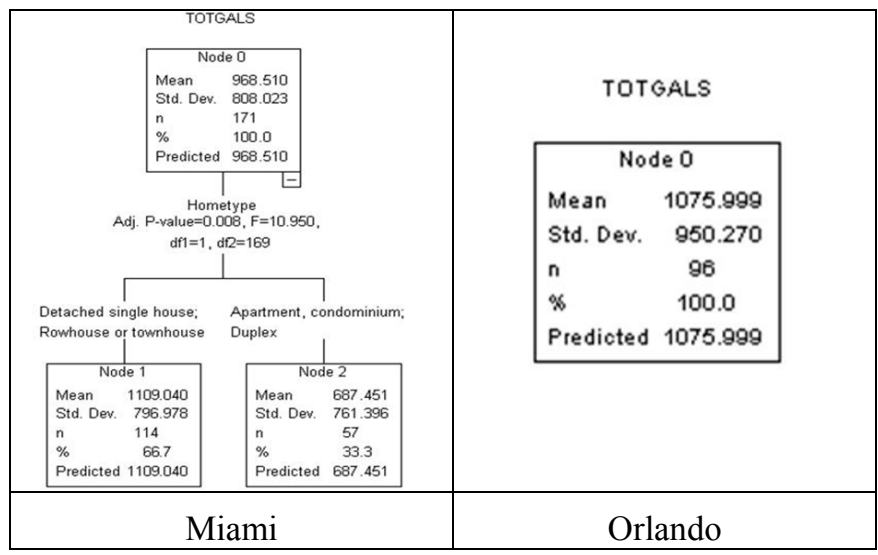

Fig. 2 CHAID analysis

Conventional wisdom illustrates that energy use increases as travel behavior becomes growing. Correlation analysis present reasonable evidence that VMT is positively correlated with energy use by approximately $96 \%$ and that residential density is negatively correlated with energy use by $26 \%$. As shown Table 3 and 4, Both correlation results for Miami and Orlando present similar coefficient that requires further analysis to find out the difference between Miami and Orlando.

Table 3 Correlation analysis (Miami)
The growing number of residential density would reduce vehicular energy use because people tend to use public transportation or walk to destination in highly dense area like MSA according to the established assumption in this paper. However, this result might stem from the VMT calculation process conducted by EIA. The Energy Information Administration tried to make up for missing values that household respondents didn't provide or fault information in 2001 NHTS dataset. They insert and compose the 2001 NHTS data to create VMT and fuel use data.

Other density indicators like employment density and population density show also negative relationship with energy use. Lindsey et al. confirms the density relation with energy use which supports the correlation of this paper [2]. Specifically, suburban density development has more energy use and GHG per capita by a factor of 2.0-2.5 than highly dense CBD. Ewing \& Cevero has done extensive literature review and analyzes density, VMT, and energy use by simply relying on elasticity values [2]. The result also articulates that energy use and VMT increase when density increase.

\begin{tabular}{|c|c|c|c|c|c|c|c|c|c|c|c|c|}
\hline Miami & $\begin{array}{c}\text { Energy } \\
\text { Use }\end{array}$ & VMT & $\begin{array}{l}\text { Housing } \\
\text { units per } \\
\text { sq mile }\end{array}$ & $\begin{array}{l}\text { Workers } \\
\text { per } \\
\text { square } \\
\text { mile }\end{array}$ & $\begin{array}{l}\text { Population } \\
\text { Density }\end{array}$ & $\begin{array}{c}\text { Number } \\
\text { of } \\
\text { Drivers }\end{array}$ & $\begin{array}{l}\text { Number } \\
\text { of } \\
\text { Workers }\end{array}$ & Income & $\begin{array}{c}\text { Number } \\
\text { of } \\
\text { vehicles }\end{array}$ & $\begin{array}{c}\text { Number } \\
\text { of } \\
\text { Adults }\end{array}$ & $\begin{array}{l}\text { Number } \\
\text { of house } \\
\text { member }\end{array}$ & Age \\
\hline Energy Use & 1.00 & & & & & & & & & & & \\
\hline VMT & 0.96 & 1.00 & & & & & & & & & & \\
\hline $\begin{array}{l}\text { Residential } \\
\text { Density }\end{array}$ & -0.26 & -0.24 & 1.00 & & & & & & & & & \\
\hline $\begin{array}{l}\text { Employment } \\
\text { Density }\end{array}$ & -0.05 & -0.01 & 0.44 & 1.00 & & & & & & & & \\
\hline $\begin{array}{l}\text { Population } \\
\text { Density }\end{array}$ & -0.14 & -0.11 & 0.78 & 0.51 & 1.00 & & & & & & & \\
\hline \# drivers & 0.45 & 0.46 & -0.31 & 0.04 & -0.18 & 1.00 & & & & & & \\
\hline \# workers & 0.48 & 0.47 & -0.24 & 0.01 & -0.11 & 0.66 & 1.00 & & & & & \\
\hline Income & 0.09 & 0.09 & -0.11 & -0.01 & -0.21 & 0.17 & 0.19 & 1.00 & & & & \\
\hline \# vehicles & 0.57 & 0.51 & -0.26 & -0.01 & -0.18 & 0.66 & 0.59 & 0.09 & 1.00 & & & \\
\hline \# Adults & 0.38 & 0.39 & -0.20 & 0.11 & -0.11 & 0.86 & 0.64 & 0.13 & 0.61 & 1.00 & & \\
\hline $\begin{array}{l}\text { Household } \\
\text { Size }\end{array}$ & 0.41 & 0.41 & -0.27 & -0.08 & -0.18 & 0.63 & 0.54 & 0.18 & 0.47 & 0.66 & 1.00 & \\
\hline Age & -0.32 & -0.29 & 0.27 & 0.22 & 0.17 & -0.19 & -0.44 & -0.14 & -0.22 & -0.17 & -0.36 & 1.00 \\
\hline
\end{tabular}


Table 4 Correlation analysis (Orlando)

\begin{tabular}{|c|c|c|c|c|c|c|c|c|c|c|c|c|}
\hline Orlando & $\begin{array}{c}\text { Energy } \\
\text { Use }\end{array}$ & VMT & $\begin{array}{c}\text { Housing } \\
\text { units } \\
\text { per sq } \\
\text { mile }\end{array}$ & $\begin{array}{l}\text { Workers } \\
\text { per } \\
\text { square } \\
\text { mile }\end{array}$ & $\begin{array}{l}\text { Population } \\
\text { Density }\end{array}$ & $\begin{array}{c}\text { Number } \\
\text { of } \\
\text { Drivers }\end{array}$ & $\begin{array}{l}\text { Number } \\
\text { of } \\
\text { Workers }\end{array}$ & Income & $\begin{array}{c}\text { Number } \\
\text { of } \\
\text { vehicles }\end{array}$ & $\begin{array}{c}\text { Number } \\
\text { of } \\
\text { Adults }\end{array}$ & $\begin{array}{c}\text { Number } \\
\text { of } \\
\text { house } \\
\text { member }\end{array}$ & Age \\
\hline Energy Use & 1.00 & & & & & & & & & & & \\
\hline VMT & 0.96 & 1.00 & & & & & & & & & & \\
\hline $\begin{array}{c}\text { Residential } \\
\text { Density }\end{array}$ & -0.18 & -0.20 & 1.00 & & & & & & & & & \\
\hline $\begin{array}{c}\text { Employment } \\
\text { Density }\end{array}$ & -0.10 & -0.11 & 0.79 & 1.00 & & & & & & & & \\
\hline $\begin{array}{c}\text { Population } \\
\text { Density }\end{array}$ & -0.14 & -0.17 & 0.77 & 0.91 & 1.00 & & & & & & & \\
\hline \# drivers & 0.45 & 0.42 & -0.14 & -0.11 & -0.18 & 1.00 & & & & & & \\
\hline \# workers & 0.34 & 0.35 & 0.20 & 0.23 & 0.17 & 0.53 & 1.00 & & & & & \\
\hline Income & 0.32 & 0.33 & -0.10 & -0.08 & -0.11 & 0.24 & 0.25 & 1.00 & & & & \\
\hline \# vehicles & 0.59 & 0.58 & -0.22 & -0.17 & -0.25 & 0.76 & 0.45 & 0.30 & 1.00 & & & \\
\hline \# Adults & 0.43 & 0.40 & -0.18 & -0.14 & -0.19 & 0.85 & 0.48 & 0.20 & 0.71 & 1.00 & & \\
\hline Household Size & 0.30 & 0.30 & 0.03 & -0.01 & -0.12 & 0.66 & 0.45 & 0.19 & 0.50 & 0.66 & 1.00 & \\
\hline Age & -0.27 & -0.31 & -0.03 & -0.08 & -0.04 & -0.09 & -0.34 & -0.11 & -0.14 & -0.01 & -0.33 & 1.00 \\
\hline
\end{tabular}

Table5 shows that there is little collinearity among independent variables when dependent variable is energy use.

Table5 Collinearity Analysis

\begin{tabular}{c|c|c|c|c}
\hline \multicolumn{2}{|c|}{} & \multicolumn{2}{|c|}{ Miami } & \multicolumn{2}{c}{ Orlando } \\
\hline Variable & Tolerance & VIF & Tolerance & VIF \\
\hline VMT & 0.65 & 1.53 & 0.57 & 1.76 \\
\hline Residential Density & 0.33 & 3.04 & 0.32 & 3.11 \\
\hline Employment Density & 0.67 & 1.50 & 0.14 & 7.30 \\
\hline Population Density & 0.32 & 3.11 & 0.14 & 7.10 \\
\hline \# drivers & 0.21 & 4.82 & 0.20 & 4.97 \\
\hline \# workers & 0.41 & 2.47 & 0.52 & 1.92 \\
\hline Income & 0.88 & 1.14 & 0.85 & 1.18 \\
\hline \# vehicles & 0.48 & 2.10 & 0.31 & 3.18 \\
\hline \# Adults & 0.22 & 4.58 & 0.21 & 4.73 \\
\hline Household Size & 0.47 & 2.13 & 0.39 & 2.58 \\
\hline Age & 0.67 & 1.49 & 0.64 & 1.55 \\
\hline
\end{tabular}

As shown in Table 6, to eliminate and reduce collinearity, factor score analysis is conducted to find some facts that urban density factor shows that the highest cumulative percentage but socioeconomic factor and demographic factor have weak explicability. In addition, Fig. 3 and Fig. 4 show the result of SEM analysis for each area.

Table 6 Factor Score Analysis

\begin{tabular}{|c|c|c|c|c|c|}
\hline & & \multicolumn{2}{|c|}{ Miami } & \multicolumn{2}{|c|}{ Orlando } \\
\hline $\begin{array}{c}\text { Item } \\
\text { (Miami) }\end{array}$ & variable & $\begin{array}{l}\text { factor } \\
\text { score }\end{array}$ & $\begin{array}{l}\text { culmulative } \\
\text { percentage }\end{array}$ & $\begin{array}{l}\text { factor } \\
\text { score }\end{array}$ & $\begin{array}{l}\text { culmulative } \\
\text { percentage }\end{array}$ \\
\hline \multirow{4}{*}{$\begin{array}{c}\text { Socioecon } \\
\text { omic } \\
\text { factor }\end{array}$} & \# drivers & 0.889 & \multirow{4}{*}{58.151} & 0.884 & \multirow{4}{*}{58.365} \\
\hline & \# workers & 0.859 & & 0.741 & \\
\hline & Income & 0.295 & & 0.499 & \\
\hline & \# vehicles & 0.844 & & 0.869 & \\
\hline \multirow{3}{*}{$\begin{array}{c}\text { Demograp } \\
\text { hic } \\
\text { factor }\end{array}$} & \# Adults & 0.834 & \multirow{3}{*}{61.104} & 0.836 & \multirow{3}{*}{58.102} \\
\hline & $\begin{array}{l}\text { Household } \\
\text { Size }\end{array}$ & 0.907 & & 0.930 & \\
\hline & Age & 0.561 & & -0.423 & \\
\hline \multirow{3}{*}{$\begin{array}{c}\text { Urban } \\
\text { Density }\end{array}$} & $\begin{array}{l}\text { Residential } \\
\text { Density }\end{array}$ & 0.888 & \multirow{3}{*}{72.262} & 0.904 & \multirow{3}{*}{88.374} \\
\hline & $\begin{array}{c}\text { Employment } \\
\text { Density }\end{array}$ & 0.735 & & 0.961 & \\
\hline & $\begin{array}{l}\text { Population } \\
\text { Density }\end{array}$ & 0.916 & & 0.954 & \\
\hline
\end{tabular}

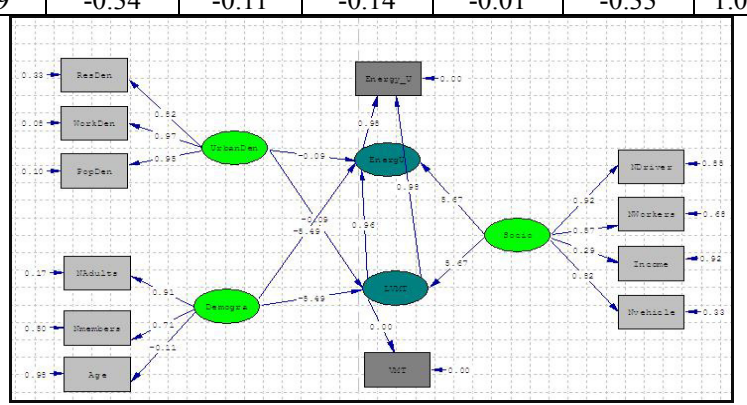

Fig. 3 Result of SEM analysis (Miami)

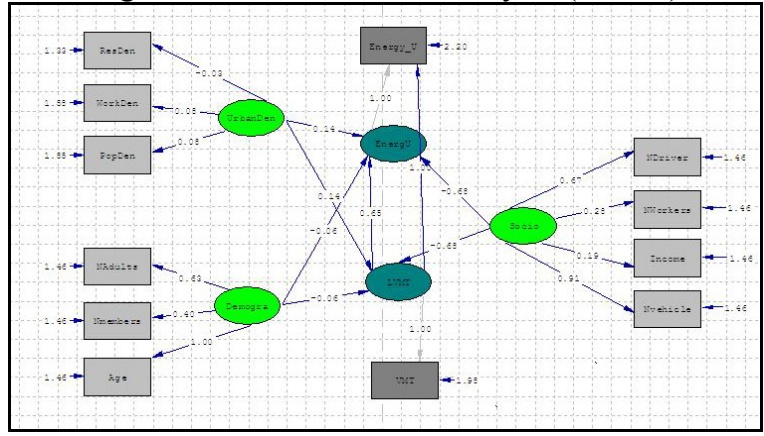

Fig. 4 Result of SEM analysis (Orlando)

With the three compressed factors, energy use and VMT variables are inserted, combined and analyzed by SEM. Analysis result for Miami are different than research hypothesis that socioeconomic, demographic factor, and urban density positively affect VMT and energy use. As demographic factor and urban density increases, VMT decreases. In contrast, the results for Orlando provide different fact that even though demographic coefficient is close to zero and urban density negatively influences VMT, only demographic show negative relationship with energy use.

\section{Conclusion}

This paper analyzes NHTS 2001 combined with EIA augmentation data and Census data and to identify 
relationship between energy use by car and greenhouse gas emission, in particular, related to residential density. The results prove that Miami and Orlando are different in terms of urban compactness and energy use. Descriptive statistics presents evidence that Miami is denser than Orlando and that density factor in Miami is stronger than one in Orlando. This indicates some inference that is related to urban sprawl and compact development. More vehicles, more drivers, more incomes, and more workers means high VMT and high energy use, which implies that they are more sprawl. This is also supported by CHAID analysis. Low density housing development demonstrates about doubling Energy Use of high density housing development. So what results provide beneficial implication for policy? Do we have to control urban sprawl in order to reduce energy use and VMT? Should we direct urban policy toward compact development? If one suggests, impact fee is one of the best alternative that make it possible to control sprawl and related externalities. Couple of studies shows that impact fee increase urban density [14]. However, ongoing arguments create a lot of research work focusing on disadvantage of impact fee. Therefore, the study for impact fee and energy use would be reservation for the next research topic.

\section{References}

[1] Brownstone, D., Golob, T. F., "The impact of residential density on vehicle usage and energy consumption", Journal of Urban Economics, Vol. 65, pp. 91-98, 2009.

[2] Ewing, R., and R. Cervero., Travel and the Built Environment: A Synthesis, Transportation Research Record, 1780, pp. 87-114, 2001.

[3] Lindsey, M., Gray, K., Schofer, J. L., \& DurangoCohen, P. L., Effect of Residential Location on Vehicle Miles of Travel, Energy Consumption, and Greenhouse Gas Emissions: Chicago Case Study. Paper presented at the Transportation Research Board 88th Annual Meeting from http://pubsindex.trb.org/orderform.html, 2009.
[4] Miron, John R., Housing Demand, Coping Strategy, and Selection Bias. Growth and Change, Vol. 35(2), pp. 220-261, 2004.

[5] Newman, P. and J. Kenworthy., Costs of automobile dependence: global survey of cities. Transportation Research Record, 1670, pp. 17-26, 1999.

[6] Newman, W.G. and J.R. Kenworthy,"Gasoline consumption and cities", Journal of the American Planning Association, Vol. 55, pp. 24-35, 1989a.

[7] Newman, W.G. and J.R. Kenworthy, A Global View of Automobile Dependence. Brookfield, VT: Gower, 1989b.

[8] Norman, J., MacLean, H. and Kennedy, C., "Comparing high and low residential density: lifecycle analysis of energy-use and greenhouse gas emissions", Journal of Urban Planning and Development, Vol. 132(1), pp. 10-21, 2006.

[9] Maat, Kees, Timmermans, Harry J.P., Influence of the residential and work environment on car use in dual-earner households, Transportation Research Part A 43, pp. 654664, 2009.

[10] Mindali, O. Raveh, Adi, Salomon, Ilan., Urban density and energy consumption: a new look at old statistics, Transportation Research Part A 38, pp 143-162, 2004.

[11] ORNL (2009). Transportation Energy Data Book, Oak Ridge National Laboratory for the U.S Department of Energy.

[12] Todd Litman., Evaluating Transportation Land Use Impacts Considering the Impacts, Benefits and Costs of Different Land Use Development Patterns, Victoria Transport Policy Institute, 2009.

[13] TRB., Special Report 298: Driving and the Built Environment: The Effects of Compact Development on Motorized Travel, Energy Use, and CO2 Emissions. The National Academies, Washington, D.C., 2009.

[14] Turnbull, G.K., "Urban growth controls : transitional dynamics of development fees and growth boundaries" Journal of Urban Economics, Vol, 55, pp. 215-237, 2004. 